\title{
Neuroprotective Treatment Strategies for Delayed Cerebral Ischemia after Subarachnoid Hemorrhage - Review of Literature and Future Prospects
} Thomas Westermaier*

Department of Neurosurgery, University Hospital Wuerzburg, Josef-Schneider-Str. 11, 97080 Wuerzburg, Germany

\begin{abstract}
This article reviews experimental and clinical data on the use of various neuroprotective agents and therapeutic measures after aneurysmal subarachnoid hemorrhage (SAH). While calcium antagonists have been used in the past and are still part of the standard treatment regimen in most departments involved in the treatment of SAH, other classes of drugs and various other methods have been tested for their potential to inhibit delayed ischemia after $\mathrm{SAH}$. This article reviews the literature about clinical studies about the efficacy of various neuroprotective agents and methods including statins, steroids and Endothelin-antagonists and other - alternative - methods like cisternal lavage, intrathecal drug delivery and hypercapnia, offering future perspectives for the treatment of this hazardous disease.
\end{abstract}

Keywords: Subarachnoid hemorrhage; Neuroprotection; Delayed cerebral infarction; Delayed ischemic neurological deficit

\section{Introduction}

Delayed ischemic neurological deficit (DIND) and delayed cerebral infarction (DCI) are the most important postoperative risk factors for poor outcome after aneurysmal subarachnoid hemorrhage (SAH) [1]. Aneurysmal SAH is associated with a total mortality of estimately $50 \%$ including patients who die before admission to a hospital. In spite of new diagnostic tools, modern intensive care therapy and early aneurysm occlusion, the in-hospital mortality has remained at 25\% [2] A large part of the surviving patients does not recover their pre-hemorrhage state [3]. Thus, SAH causes great personal harm and a great economical burden to health systems.

Early brain damage in the first minutes after rupture of an aneurysm cannot be treated or reversed, as it usually occurs outside hospital walls. Treatment can begin when emergency physicians or paramedics have the first contact with the patient. At first, only general measures of treatment can be undertaken like analgesic therapy, application of oxygen or sometimes intubation and mechanical ventilation. Targeted therapy can be initiated not before the diagnosis of SAH has been established by a CT-scan. Later in the course of the disease, the patients are threatened by delayed ischemic events which arise several days after aneurysm rupture. Concerning these delayed perfusion deficits; however, there is the unique opportunity to start therapeutic measures in advance, before cerebral blood flow (CBF) declines below ischemic thresholds [4]. Various forms of treatment have been tested and used to enhance $\mathrm{CBF}$ and protect the brain from ischemic deficits. Among these, different calcium antagonists are the most prominent substances. Following the growing knowledge about pathophysiological mechanisms, a variety of further agents have been tested for their therapeutic efficacy.

\section{Pathophysiology}

Aneurysmal SAH is characterized by 3 different forms of cerebral ischemia. First, global ischemia develops immediately after aneurysm rupture. The extravasation of blood into the subarachnoid space causes an increase of intracranial pressure (ICP) and subsequently a decrease of cerebral perfusion pressure (CPP). This stage of the disease cannot be therapeutically influenced because it occurs outside hospitals and before the diagnosis of SAH is established. An acute global vascular reaction also arises in the first seconds or minutes after aneurysm rupture, affects the entire cerebral vasculature at least for several hours even when CPP has recovered to normal [5].

In the following days, a variety of local factors lead to endothelial dysfunction and changes in the contraction state of the vessels. They finally lead to structural changes of the vessel wall with intimal thickening and media proliferation [6]. Several days after SAH, delayed vasospasm develops in up to $70 \%$ of all patients who suffered from $\mathrm{SAH}$. Until now, the exact pathogenesis is not clarified. Inflammatory processes are involved in this phenomenon and contribute to arterial narrowing [7]. The amount of subarachnoid blood is a good prognostic factor for the development of cerebral vasospasm and DIND indicating that hemoglobin in the subarachnoid space is the antigen that causes inflammatory reactions $[8,9]$.

Nitric oxide (NO) induces the generation of cyclic guanosyl monophosphate (cGMP) which results in vasodilatation by several mechanisms $[10,11]$. Due to its high affinity, NO binds to hemoglobin, resulting in an NO-depletion. The number of perivascular neurons which carry relatively high amounts of NO and supply the large intracranial vessels, is decreased after SAH causing a further decrease of NO [12,13].

Free radicals are produced after SAH by a decay of leukocytes and by autooxidation of hemoglobin $[7,14]$. The degradation of membrane proteins and lipids are the consequence of the free radical activity resulting in a damage of endothelial cells, smooth muscle cells and perivascular neurons. Vasoactive substances are liberated, especially arachidonic acid metabolites. A direct inflow of calcium into vascular smooth muscle cells may be caused by a damage of the membrane integrity.

Hemoglobin induces a radical-mediated damage of the cell

*Corresponding author: Thomas Westermaier, University Hospital Wuerzburg Department of Neurosurgery, Josef-Schneider-Str. 1197080 Wuerzburg, Germany, Tel: +49-931-24527; Fax: +49-931-24551; E-mail: westermaier.t@nch.uni-wuerzburg.de

Received November 28, 2013; Accepted December 23, 2013; Published December 31, 2013

Citation: Westermaier T (2013) Neuroprotective Treatment Strategies for Delayed Cerebral Ischemia after Subarachnoid Hemorrhage - Review of Literature and Future Prospects. J Neurol Neurophysiol 5: 183. doi:10.4172/2155-9562.1000183

Copyright: $\odot 2013$ Westermaier T. This is an open-access article distributed under the terms of the Creative Commons Attribution License, which permits unrestricted use, distribution, and reproduction in any medium, provided the original author and source are credited. 
membrane and an activation of Phospholipase $\mathrm{A}_{2}$. Finally, a shift towards constrictive arachidonic acid metabolites occurs. The level of prostacyclin is reduced in the cerebral spinal fluid (CSF) of SAHpatients who develop delayed vasospasm [15].

Endothelin-1 is the most powerful vasoconstrictive factor known to date. It has been found to be elevated in blood and CSF of patients who develop vasospasm after SAH. The elevation of Endothelin-1 levels correlate with the severity of vasospasm [16].

The extravasation of hemoglobin into the subarachnoid space is a toxic stimulus. The immune system reacts with a specific answer. Several hours after SAH, cellular adhesion molecules are found on the luminal surface of endothelial cells [17]. An inflammatory cascade develops, including the adhesion and extravasation of leukocytes. Different from other types of tissue, there is no clearance of the subarachnoid space by the lymphatic system. Therefore, leukocytes decay and vasoactive substances like Endothelin-1 and free radicals are set free. Cerebral vasospasm is likely not to be monofactorial.

Today all these processes are thought to be factors of the development of arterial narrowing which is probably the basis of secondary ischemia evolving several days after aneurysmal SAH. However, arterial vasospasm seems not to be the only factor for the development of DCI after SAH. It has been shown that - although less frequently - DCI after SAH can occur without significant cerebral vasospasm [18]. On the other hand, the number of patients suffering from arterial vasospasm is much higher than the number of patient's developing DCI [19]. Additional pathophysiological mechanisms have been proposed to induce secondary ischemia after SAH. Dreier et al. [20] and Pluta et al. [21] suggested a double-hit model of secondary ischemia in which mechanisms causing ion disturbances and hypermetabolism are superimposed on arterial narrowing and, in combination, cause DCI. Although the aetiology of DCI is not exactly known, all pathophysiological factors are likely to finally turn into a discrepancy between the supply and demand of oxygen in the brain. Following the growing knowledge about pathophysiological mechanisms, several attempts have been conducted to treat or prevent secondary ischemia after SAH and improve the outcome of SAHpatients.

\section{Evidence for Drug Effectiveness in Clinical Trials}

There is, at present, no specific agent of method that has proven clear efficacy for the treatment of early ischemia after SAH. The early management of SAH-patients includes intubation and mechanical ventilation if normal ventilation and oxygenation are at risk, ventriculostomy in case of occlusive hydrocephalus, medical treatment of elevated intracranial pressure (ICP), and early treatment of the aneurysm by surgical clipping or endovascular coiling, moderate hyper dynamic therapy to secure cerebral perfusion and the avoidance of medical complications. As secondary ischemic events after SAH occur with a delay of several days, there is the chance to start a specific neuroprotective treatment prior to ischemia. This is decisively different to embolic stroke which hits the patient at home or "in the field", in most cases without prior warning signals [22]. A variety of substances have been tested in clinical trials.

\section{Corticosteroids}

Inflammatory reactions are believed to be a decisive factor for the development of arterial narrowing after SAH $[7,17]$. Corticosteroids have an antiinflammatory effect, stabilize cell membranes and address the radical-induced cell damage and the effect of the calcium-influx into endothelial cells, smooth muscle cells, neurons and glial cells mediated by Phospholipase $\mathrm{A}_{2}$. The effectiveness of a high-dose therapy with corticosteroids after aneurysmal SAH, however, is not clarified to date. The mineralocorticoid fludrocortisone $[23,24]$ and the glococotricoid hydrocortisone [25] have been tested in clinical studies. In a metaanalysis, the therapy with corticosteroids did not show a distinct benefit for the patients [26]. Separately analyzed, the treatment with mineralocorticoids resulted in less ischemic complications. Serious side effects like gastrointestinal bleedings and electrolyte imbalance prevented a beneficial effect on outcome parameters in the treatment with hydrocortisone. In summary, the number of patients included in these three clinical trials is too small (256 patients) and the studies too inhomogenous to indicate a clear benefit of a corticosteroid treatment. Recently, a randomized, placebo-controlled clinical trial was published in which 95 patients with aneurysmal SAH received methylprednisolone in a daily dose of $16 \mathrm{mg} / \mathrm{kg}$ body weight for 3 days. The treatment resulted in an improvement of clinical outcome which nearly reached the level of significance [27].

\section{Tirilazad}

Tirilazad mesylate is a 21 -aminostroid with only very little mineralo- and glococorticoid activity. It acts as a radical scavenger and membrane protector [28]. The substance inhibits the free radicalmediated damage of endothelial membranes and neurons. After promising results in experimental studies several clinical trials were conducted. In all of these studies, patietns were co-treated with the calcium antagonist nimodipine. A meta-analysis showed that the delayed arterial narrowing was reduced by treatment with tirilazad. However, this effect was not accompanied by a significant reduction of DCI and improvement of neurological outcome [29].

\section{Statins}

Hydroxymethylglutaryl coenzyme A reductase inhibitors, so-called "statins", have a variety of properties which may potentially inhibit cerebral vasospasm. Among those are antiinflammatory activity and endothelial cell protection. Several clinical trials have been conducted. Early clinical studies revealed a lower incidence of cerebral vasospasm, vasospasm-related neurological deficits and mortality [30,31]. However, these trial were small and the end points varied strongly. More recent trials reported less promising results as they could not clearly reproduce the positive effects on vessel narrowing, DCI and neurological outcome $[32,33]$. The attempt to generate a Cochrane Review failed due to the poor quality of some trials and the inhomogenity of the available trials [34]. A closing statement about the usefulness of a statin treatment after SAH cannot be drawn. Further trials are on the way [35,36].

\section{Endothelin-receptor antagonists}

Three randomized clinical studies have been published in literature. One trial investigated a non-selective $\left(\mathrm{ET}_{\mathrm{A}} / \mathrm{ET}_{\mathrm{B}}\right)$ Endothelin-receptor antagonist (TAK-044), two investigated the selective $\mathrm{ET}_{\mathrm{A}}$-receptor antagonist Clazosentan [37-39]. The objective was to antagonize the strong vasoconstrictive activity exerted by $\mathrm{ET}_{\mathrm{A}}$-receptors as Endothelin-1 concentrations are elevated in both blood and CSF of SAH-patients who develop delayed cerebral vasospasm.

A total of 867 patients was included in these trials. The treatment resulted in a distinct reduction of arterial narrowing (Odds Ratio (OR) 0.31). The incidence of DCI was less pronounced (OR 0.68) and there was only a marginal improvement of neurological outcome, determined as good (Glasgow outcome scale (GOS) 4 and 5) versus bad (GOS 1-3) outcome (OR 0.87). Mortality was even increased (OR 1.09) 
[40]. The discrepancy between delayed cerebral vasospasm and DCI may be explainable by a hypotensive effect of $\mathrm{ET}_{\mathrm{A}}$-receptor antagonists, which may prevent an improvement of cerebral perfusion in spite of attenuated arterial narrowing. The discrepancy between the reduced incidence of DCI and the failure to improve clinical outcome and even increased mortality may be explained by serious systemic side effects like pneumonia and pulmonary edema [40].

\section{Calcium antagonists}

In the 1980s and 1990s, a series of clinical trials was conducted to test the efficacy of pyrrolopyrimidine-type calcium antagonists. These substances were applied to inhibit cellular calcium influx in cerebrovascular smooth muscle cells via voltage-dependent L-type calcium channels which were suspected to be responsible for the occurrence of delayed cerebral vasospasm after SAH. It was registered rather quickly, that this kind of treatment did not prevent or dissolve arterial vasospasm. In a British clinical multicenter trial, however, a reduced incidence of DCI and improvement of clinical outcome by the oral treatment with nimodipine was observed [41]. Although this was the largest clinical trial, it was the only one that observed a significant benefit. A series of other trials with nimodipine and other calcium antagonists failed to reduce the incidence of DCI and improve outcome after SAH. A Cochrane Review edited in 2007 analyzed 7 prospective, randomized, placebo-controlled clinical trials with nimodipine and recommended its prophylactic administration in SAH-patients. However, the authors concluded that this recommendation was not "beyond any doubt". If the above mentioned British multicenter trial was taken out of the statistical analysis, no more benefit over a placebotreatment could be calculated [42].

The prophylactic treatment with nimodipine has become a standard therapy in many centers. However, its standard use must be critically reviewed as there is a variety of conflicting issues regarding nimodipine. There is no evidence for the intravenous use, which was initially promoted by the manufacturer. The information about the oral uptake of the agent is scarce. In patients who are mechanically ventilated, oral nimodipine has to be administered via a stomach tube. Especially in the weaning phase after several days of mechanical ventilation, which parallels in many cases the period of maximum vasospasm, gastral reflux makes the uptake of orally administered substances incalculable. Nimodipine can cause hypotension and can open pulmonary arteriovenous shunts resulting in oxygenation problems. Finally, the meta-analyses about the use of calcium antagonists that are available today, refer to clinical trials that were conducted more than 25 years ago. The objective for a treatment with nimodipine and other calcium antagonists was the avoidance of delayed cerebral perfusion deficits. In the past 25 years, however, intensive care therapy has improved, many aneurysms are treated by endovascular coiling, and endovascular balloon dilatation and pharmacological vasospasmolysis are used to treat critical arterial narrowing of cerebral vessels and improve CBF [43]. The prerequisites have changed and it is doubtful whether a prophylactic oral treatment with nimodipine would still exert a beneficial effect under modern treatment standards [44]

\section{Magnesium sulfate}

Magnesium has been called "nature's physiologic calcium blocker" as it is a physiological mineral and interferes with calcium in a variety of ways [45]. The bivalent magnesium cation can compete with calcium ions for receptor binding or passage through ion channels. It dilates blood vessels by competitive inhibition of voltage-dependent calcium channels in vascular smooth muscle cells [46], improves rheological functions by inhibition of platelet aggregation $[47,48]$, and increases the deformability of red blood cells [49]. Under experimental conditions, it prevents cellular calcium influx and excitatory amino acid release in neurons by blockade of N-type and L-type calcium channels [50], prevents cellular calcium entry through NMDA-receptor channels [51], reduces calcium-induced mitochondrial dysfunction [52] and preserves cellular energy metabolism [53]. By these mechanisms, magnesium may inhibit or delay ischemic cell death during and after cerebral ischemic events.

Low blood pressure is a risk factor for aggravation of ischemic damage in states of cerebral ischemia reducing collateral flow in the ischemic penumbra. Therefore, magnesium doses must be kept low enough to ensure stable blood pressure if it is administered for the purpose of neuroprotection. In an experimental study of temporary middle cerebral artery occlusion (MCAO) in rats, serum concentrations of $2.0-2.5 \mathrm{mmol} / 1$ showed the highest neuroprotective effect [54]. In higher doses, the cardiodepressive effect seems to limit the extent of neuroprotection.

The potential role for a treatment with magnesium was supported by the observation that hypomagnesemia is frequently found in $\mathrm{SAH}$ patients and correlates with the amount of blood in the subarachnoid space and with the patient's neurological condition at the time of hospital admission. Hypomagnesemia arising during the course of treatment, in turn, correlates with the appearance of secondary neurological deficits and ischemic infarctions [55]. A series of clinical trials has been launched to assess the ability to reduce secondary neurological deficits after SAH. Several small observational studies and placebocontrolled studies using different doses of intravenous magnesium sulfate produced promising results [56-61]. In a randomized, placebocontrolled multicenter study conducted by van den Bergh et al., patients received a daily dose of $64 \mathrm{mmol} \mathrm{MgSO}_{4}$ for 14 days. The results were promising. Magnesium treatment reduced the risk of DCI by $34 \%$ and the risk for poor outcome by $23 \%$. Including 283 patients, however, the study was still underpowered [62]. In a south-east Asian/Australian trial, 327 patients were randomized to receive placebo or a daily dose of $80 \mathrm{mmol} / \mathrm{l} \mathrm{MgSO}$. The authors reported no significant benefit of magnesium-treatment regarding DCI and neurological outcome after 6 months [63]. The largest clinical trial has been conducted by Mees et al. In this multicenter trial, 1,204 patients with aneurysmal SAH were enrolled and randomized to receive $64 \mathrm{mmol} \mathrm{MgSO}_{4}$ per day or placebo. The administration of $\mathrm{MgSO}_{4}$ did not improve clinical outcome at an end point 3 months after SAH [64].

These results also require a critical analysis. Except for a very small early clinical trial conducted by Luo et al. [56], who compared magnesium treatment to a true placebo group, all patients enrolled in these trials were co-treated with nimodipine. The authors of the latter studies conclude that intravenous magnesium fails to improve neurological outcome and mortality in spite of decreasing the incidence of DCI [65]. Among the trials, magnesium doses varied significantly. However, it is noticeable that all studies that found no benefit of magnesium-treatment used nimodipine as a "standard-treatment" which was administered to both the treatment-group and the "controlgroup". Schmid-Elsaesser et al. compared treatment with magnesium to treatment with nimodipine. Patients of the magnesium-group did not receive nimodipine. The authors did not register a significant difference between the two treatments arms [66]. In our own study, magnesiumtherapy was compared to a true placebo-group and resulted in a significant improvement of DCI and arterial spasm. Nimodipine was given to neither of both groups [67]. The combined administration 
of magnesium and nimodipine is a combination therapy with two calcium antagonists. Therefore, it is not surprising that this treatment does not result in an additional effect as it is commonly known that the effect of a combination therapy is not necessarily the sum of its single components, in particular if both drugs have - in part or in total - the same mechanisms of action. The doses and co-medications vary too much to finally judge at this point whether magnesium may be an effective drug after aneurysmal SAH.

In summary, the pharmacological attempts that have been conducted in the past were disappointing. The number of high-quality studies testing the efficacy of corticosteroids and statins is too small to supply evidence for their use in SAH-patients [25,34], radical scavengers and Endothelin-receptor antagonists have shown a positive effect regarding the treatment of delayed cerebral vasospasm but resulted in no improvement of DCI and neurological outcome $[29,30]$. Nimodipine has become a standard treatment on many centers although its use is not "beyond any doubt" as a Cochrane Review has stated [42]. Furthermore, the data on which the evidence for nimodipine-treatment bases, is more than 25 years old. In the meantime, treatment of aneurysms and vasospasm has been improved and a re-evaluation of nimodipine under new treatment standards must be called for [44]. Magnesium is cheap and safe to handle. However, recent trials have not found a significant protective effect if administered in addition to nimodipine [63,64]. If given without co-treatment with other calcium antagonists, it has shown a protective effect and might still be a promising substance in SAH-patients $[66,67]$. Due to these disappointing results, alternative methods may be interesting for the treatment of secondary ischemia after aneurysmal SAH.

\section{Alternative Treatment Strategies and Future Prospects}

Various attempts other than the systemic - oral or intravenous administration of drugs have been conducted in order to treat delayed cerebral vasospasm and DCI. Some of these may have a high potential to become important forms of treatment.

\section{Subarachnoid washout}

Subarachnoid blood or - more precisely - hemoglobin is the antigen that induces inflammatory reactions which ultimately lead to changes in the vessel walls and arterial narrowing [7]. The amount of subarachnoid blood determines the extent of delayed cerebral vasospasm [8]. In animal studies, the injection of blood into the subarachnoid space reproducibly leads to cerebral vasospasm with a delay of several days [68]. The removal of the subarachnoid blood clot may prevent or alleviate cerebral vasospasm if it is performed early enough $[69,70]$. In the practical setting, however, a complete or near-complete removal of the subarachnoid blood clot during aneurysm surgery seems too dangerous and is not reasonable. Several studies have been conducted to dissolve the blood clot by fibrinolytic agents. First clinical experience was gathered in the 1980s. Tsementzis et al. reported that this method is safe in SAH-patients [71]. In a small number of patients, Hamada et al. administered urokinase via an intrathecal catheter and found a complete removal of the subarachnoid blood clot as visible in CT-scans within 24 hours. None of these patients developed DCI [72]. Yamamoto et al. administered tissue plasminogen activator (tPA) continuously or intermittently via a cisternal catheter which was positioned during surgical clipping of the aneurysm and compared two treatment-groups (continuous or intermittent administration) to a control group. The authors found no relevant risks of intrathecal fibrinolytic therapy, a reduction of ischemic events and an improvement of neurological outcome in the treatment-groups favoring the intermittent administration [73]. The patient collectives were too small to draw firm conclusions. However, the absence of side effects and the positive results with regard to secondary ischemic events make intrathecal fibrinolytic therapy a promising treatment.

\section{Continuous head motion and rotational therapy for subarachnoid lavage}

The objective of this manipulation is to accelerate the washout of blood by a continuous motion of the head. This form of treatment was first described by Suzuki et al. in 1990 and later picked up by Kawamoto et al. [74,75]. Kawamoto et al. reported about a marked reduction of delayed vasospasm, DIND and DCI and an improvement of neurological outcome by continuous head motion combined with cisternal irrigation. Eicker et al. combined continuous low-frequency head motion with fibrinolytic therapy in 40 patients and reported a significant decrease of DCI [76].

\section{Intrathecal delivery of vasodilators}

To date, the intrathecal administration of vasodilators, calcium antagonists (Table 1) and sodium nitroprussid (SNP) (Table 2) has been performed in particular cases with cerebral vasospasm which is

\begin{tabular}{|c|c|c|c|c|c|c|}
\hline Author & Agent and application & Patient collective & Results & $\begin{array}{l}\text { Methodical side } \\
\text { effects }\end{array}$ & $\begin{array}{l}\text { Pharmacological } \\
\text { side effects }\end{array}$ & Remark \\
\hline $\begin{array}{c}\text { Shibuya et al., } \\
1994 \text { [84] }\end{array}$ & $\begin{array}{l}\text { Nicardipine via cisternal catheter } \\
(3 \times 2 \mathrm{mg} \text { daily from day } 10-17)\end{array}$ & $\begin{array}{c}\text { Patients with high risk of } \\
\text { vasospasm (Fisher grade } 3 \text { ) } \\
\text { (50 treatment, } 91 \text { control) }\end{array}$ & $\begin{array}{l}50 \% \text { reduction of DIND, } \\
\text { reduction of angiographic } \\
\text { vasospasm }\end{array}$ & 2 Meningitis & Headache & $\begin{array}{l}\text { Not } \\
\text { randomized }\end{array}$ \\
\hline $\begin{array}{l}\text { Suzuki et al., } \\
2001[85]\end{array}$ & $\begin{array}{l}\text { Nicardipine via cisternal catheter } \\
(2 \times 4 \mathrm{mg} \text { fromday } 3-14)\end{array}$ & $\begin{array}{l}177 \text { consecutive SAH } \\
\text { patients }\end{array}$ & $\begin{array}{l}\text { Low rate of angiographic } \\
\text { vasospasm and DIND }\end{array}$ & $6 \%$ meningitis & None & $\begin{array}{c}\text { No controlled } \\
\text { study }\end{array}$ \\
\hline $\begin{array}{c}\text { Fujiwara et al., } \\
2001[86]\end{array}$ & $\begin{array}{c}\text { Nicardipin via cisternal catheter } \\
\text { (continuous administration of } 8 \\
\text { mg daily for } 14 \text { days) }\end{array}$ & $\begin{array}{c}5 \text { patients with high risk of } \\
\text { vasospasm }\end{array}$ & $\begin{array}{l}\text { No angiographic vasospasm, } \\
\text { reversible DIND in } 1 \text { patient }\end{array}$ & 1 meningitis & None & $\begin{array}{l}\text { No controlled } \\
\text { study }\end{array}$ \\
\hline $\begin{array}{c}\text { Etisham et al., } \\
2008 \text { [87] }\end{array}$ & $\begin{array}{l}\text { Nicardipin via EVD }(2 \times 4 \mathrm{mg} \\
\text { daily over several days })\end{array}$ & 6 patients with vasospasm & $\begin{array}{l}\text { Marked reduction of flow } \\
\text { velocity in TCD after nicardipine } \\
\text { administration in } 5 \text { patients }\end{array}$ & None & None & $\begin{array}{l}\text { No controlled } \\
\text { study }\end{array}$ \\
\hline $\begin{array}{c}\text { Goodson et al, } \\
2008[88]\end{array}$ & $\begin{array}{l}\text { Nicardipin via EVD }(2 \times 4 \mathrm{mg} \\
\text { daily over 5-17 days })\end{array}$ & $\begin{array}{l}8 \text { patients with refractory } \\
\text { vasospasm }\end{array}$ & $\begin{array}{l}\text { Good outcome in } 7 \text { patients, } \\
\text { death in } 1 \text { patients }\end{array}$ & None & $\begin{array}{l}\text { headache in } 1 \\
\text { patient }\end{array}$ & $\begin{array}{c}\text { No controlled } \\
\text { study }\end{array}$ \\
\hline $\begin{array}{l}\text { Hänggi et al. } \\
2008 \text { [89] }\end{array}$ & $\begin{array}{c}\text { Nimodipine }(0.4 \mathrm{mg} \text { bolus via } \\
\text { EVD followed by continuous } \\
\text { infusion of } 0.4 \mathrm{mg} / \mathrm{h} \text { via lumbar } \\
\text { drainage }\end{array}$ & $\begin{array}{c}8 \text { patients with refractory } \\
\text { vasospasm }\end{array}$ & $\begin{array}{l}\text { Immediated improvement } \\
\text { in } 3 \text { patients, improved } \\
\text { perfusion (Perfusion-CT) in } \\
70 \% \text {. Improved angiographic } \\
\text { vasospasm in } 7 \text { patients. }\end{array}$ & 1 meningitis & None & $\begin{array}{l}\text { No controlled } \\
\text { study }\end{array}$ \\
\hline
\end{tabular}

Table 1: Clinical studies on the treatment of cerebral vasospasm with calcium antagonists via cisternal or ventricular catheters (DIND=delayed ischemic neurological deficit $\mathrm{TCD}=$ transcranial Doppler sonography). 
Citation: Westermaier T (2013) Neuroprotective Treatment Strategies for Delayed Cerebral Ischemia after Subarachnoid Hemorrhage - Review of Literature and Future Prospects. J Neurol Neurophysiol 5: 183. doi:10.4172/2155-9562.1000183

\begin{tabular}{|c|c|c|c|c|c|c|}
\hline Author & Agent and application & Patient collective & Results & $\begin{array}{l}\text { Methodical } \\
\text { side effects }\end{array}$ & $\begin{array}{l}\text { Pharmacological } \\
\text { side effects }\end{array}$ & Remark \\
\hline $\begin{array}{c}\text { Thomas et al., } \\
1999 \text { [90] }\end{array}$ & $\begin{array}{l}\text { SNP via EVD or cisternal catheter } \\
\text { Group 1: } 7-88 \text { mg SNP until } \\
\text { improvement of spasm or } \\
\text { occurrence of side effect } \\
\text { Group } 2: 4-8 \text { mg SNP every } 6 \\
\text { hours for } 5-17 \text { days }\end{array}$ & $\begin{array}{l}\text { Group } 1: 15 \text { patients } \\
\text { with refractory } \\
\text { vasospasm } \\
\text { Group } 2: 10 \text { patients } \\
\text { prophylactically (Fisher } \\
\text { grade } 3 \text {, Hunt/Hess } \\
\text { grade } 3-5 \text { ) }\end{array}$ & $\begin{array}{c}\text { Group 1: improvement of } \\
\text { angiographic vasospasm in } 8 \\
\text { patients } \\
\text { Group 2: no signs of vasospasm }\end{array}$ & None & $\begin{array}{c}\text { Group 1: } \\
\text { hypotension in } 3 \\
\text { cases, nausea in } 2 \\
\text { cases } \\
\text { Group 2: None }\end{array}$ & $\begin{array}{c}\text { No controlled study, } \\
\text { not randomised }\end{array}$ \\
\hline $\begin{array}{l}\text { Thomas et al., } \\
2002 \text { [91] }\end{array}$ & $\begin{array}{c}\text { SNP+Thiosulfat via EVD }(4 \mathrm{mg} / \mathrm{ml} \\
\text { und } 10 \mathrm{mg} / \mathrm{ml}) \\
\text { "acute protocol": } 10 \mathrm{ml} \text { in } 10 \text { single } \\
\text { doses every } 5 \text { minutes } \\
\text { "prophylactic protocol": } 2 \mathrm{ml} \text { over } \\
60 \text { minutes for } 11-14 \text { days }\end{array}$ & $\begin{array}{c}\text { "acute protocol": } 10 \\
\text { patients with DIND or } \\
\text { elevated flow velocities } \\
\text { in TCD } \\
\text { "prophylactic protocol": } \\
6 \text { patients }\end{array}$ & $\begin{array}{l}\text { Improvement of DIND and flow } \\
\text { velocities in TCD in } 9 / 10 \text { cases }\end{array}$ & None & None & No controlled study \\
\hline $\begin{array}{l}\text { Raabe et al., } \\
2002 \text { [92] }\end{array}$ & $\begin{array}{l}\text { SNP via EVD or cisternal catheter } \\
\text { single bolus } 10-40 \mathrm{mg} \mathrm{(11} \\
\text { patients) } \\
\text { continuous infusion } 2-8 \mathrm{mg} \text { for } \\
7-14 \text { days }\end{array}$ & $\begin{array}{l}13 \text { patients with } \\
\text { refractory vasospasm }\end{array}$ & $\begin{array}{c}\text { Tissue oxygenation improved in } 6 \\
\text { patients with vasospasm }\end{array}$ & None & $\begin{array}{l}\text { Hypotension in } 5 \\
\text { cases, nausea in } \\
3 \text { cases, cardiac } \\
\text { arrhythmias in } 1 \\
\text { case }\end{array}$ & $\begin{array}{l}\text { No controlled study, } \\
\text { not randomized }\end{array}$ \\
\hline $\begin{array}{l}\text { Pathak et al., } \\
2003 \text { [93] }\end{array}$ & $\begin{array}{c}\text { SNP "high-dose" (5 mg every 4-12 } \\
\text { hours via EVD) } \\
\text { SNP "low-dose" (4 mg every } 6 \\
\text { hours via cisternal catheter }\end{array}$ & $\begin{array}{c}\text { "high-dose": } 5 \text { patients } \\
\text { with DIND } \\
\text { "low-dose": } 3 \text { patients } \\
\text { with SAH Fisher grade } 3\end{array}$ & $\begin{array}{l}\text { reduction of flow velocity in TCD } \\
\text { No spasm in } 2, \text { moderate spasm } \\
\text { in } 1 \text { prophylactically treated } \\
\text { patients }\end{array}$ & None & $\begin{array}{l}\text { Distinct } \\
\text { hypotension after } \\
\text { administration of } \\
\text { SNP }\end{array}$ & Not randomised \\
\hline $\begin{array}{l}\text { Kumar et al., } \\
2003 \text { [94] }\end{array}$ & $\begin{array}{c}\text { SNP via EVD } \\
\text { Repeated administration of } 4 \mathrm{mg} \\
\text { bolus }\end{array}$ & 10 patients with $\mathrm{SAH}$ & $\begin{array}{l}\text { improvement or complete } \\
\text { recovery of vasospasm in all } \\
\text { patients }\end{array}$ & None & $\begin{array}{c}\text { Nausea in higher } \\
\text { doses, hypotension } \\
\text { in } 2 \text { cases }\end{array}$ & $\begin{array}{l}\text { No controlled study, } \\
\text { not randomized }\end{array}$ \\
\hline
\end{tabular}

Table 2: Clinical trials assessing the effects of intrathecal administration of sodium nitroprussid in patients with refractory vasospasm and patients with high risk to develop vasospasm and $\mathrm{DCl}$ (SNP=sodium nitroprussid, EVD=external ventricular catheter, $\mathrm{TCD}$ =transcranial Doppler sonography).

\begin{tabular}{|c|c|c|c|c|c|c|}
\hline Author & Agent and Application & Patient Collective & Results & $\begin{array}{l}\text { Methodical } \\
\text { Side Effects }\end{array}$ & $\begin{array}{c}\text { Pharmacological } \\
\text { Side Effects }\end{array}$ & Remark \\
\hline $\begin{array}{l}\text { Dalbasti et al., } 2001 \\
\text { [95] }\end{array}$ & $\begin{array}{c}\text { Papaverin pellets } \\
\text { intraoperative positioning } \\
\text { of pellets }\end{array}$ & $\begin{array}{c}117 \text { patients with high risk of } \\
\text { vasospasm ( } 73 \text { treatment, } 44 \\
\text { control) }\end{array}$ & $\begin{array}{c}\text { marked reduction of } \\
\text { vasospsm, significant } \\
\text { improvement of outcome }\end{array}$ & None & None & No randomisation \\
\hline $\begin{array}{c}\text { Kasuya et al., } 2005 \\
{[96]}\end{array}$ & $\begin{array}{c}\text { Nicardipin pellets, } \\
\text { intraoperative positioning } \\
\text { of pellets }\end{array}$ & $\begin{array}{l}125 \text { patients with high risk of } \\
\text { vasospasm ( } 97 \text { treatment, } 28 \\
\text { control) }\end{array}$ & $\begin{array}{l}\text { mignificant reduction of } \\
\text { DIND }\end{array}$ & None & None & No randomisation \\
\hline $\begin{array}{l}\text { Krischek et al., } 2007 \\
\text { [97] }\end{array}$ & $\begin{array}{l}\text { Nicardipine pellets } \\
\text { intraoperative positioning } \\
\text { of pellets }\end{array}$ & $\begin{array}{c}100 \text { patients with high risk of } \\
\text { vasospasm (Fisher grade } 2 \\
\text { und } 3 \text { ) }\end{array}$ & $\begin{array}{l}7 \text { patients with DIND, } 5 \\
\text { patients with DCl. } \\
\text { No spasms in vicinity to } \\
\text { pellets }\end{array}$ & None & None & No randomisation \\
\hline Barth et al., 2007 [98] & $\begin{array}{l}\text { Nicardipine pellets, } \\
\text { intraoperative positioning } \\
\text { of pellets }\end{array}$ & $\begin{array}{l}32 \text { patients (16 treatment, } 16 \\
\text { control) }\end{array}$ & $\begin{array}{c}\text { reduction of angiographic } \\
\text { vasospasm and DIND, } \\
\text { improvement of neurological } \\
\text { outcome }\end{array}$ & None & None & Randomized study \\
\hline
\end{tabular}

Table 3: Clinical studies assessing the efficacy of intraoperatively positioned drug-releasing "pellets" containing vasodilating agents (DIND=delayed ischemic neurological deficit).

refractory to medical and endovascular treatment or prophylactically in patients who were considered to have a particularly high risk to develop delayed cerebral vasospasm and DIND. Apart from this, nicardipine, a calcium antagonist was prophylactically attached to cerebral vessels during surgical clipping of aneurysms in the shape of "pellets" which dissolve slowly and continuously release the agent (Table 3 ). The results were reproducibly positive as intrathecal therapy tended to prevent vasospasm and even reverse vasospasm which was refractory to medical treatment. However, there is no randomized, placebo-controlled trial which supplies good evidence for intrathecal treatment.

Again, magnesium may be a promising substance for intrathecal administration. It is a physiological component of CSF and a moderate increase of its CSF concentration is unlikely to produce serious side effects. Furthermore, the CSF concentration can easily be followed by laboratory analyses. However, experimental studies suggest that CSF concentrations of $2-4 \mathrm{mmol} / \mathrm{l}$ are necessary to dilate spastic vessels $[77,78]$. These concentrations cannot be produced by an intravenous administration of magnesium sulfate since the systemic side effects could be hazardous. Mori et al administered magnesium sulfate via a cisternal catheter in patients with cerebral vasospasm refractory to other forms of therapy and found a reduction of the extent of arterial narrowing [79], measured by transcranial Doppler sonography.

\section{Carbon dioxide}

Cerebral autoregulation upon changes of arterial blood pressure is deranged after aneurysmal SAH. The cerebrovascular reactivity on changes of arterial $\mathrm{CO}_{2}$ concentrations, however, may be altered but is still preserved [80,81]. It is well known that hyperventilation enhances cerebral perfusion deficits after SAH and induces ischemia [82].

A series of studies has been published investigating the reactivity of $\mathrm{CBF}$ on changes of arterial $\mathrm{CO}_{2}$ concentrations and their prognostic relevance for the development of DCI after SAH. Recently, Carrera et al. found that decreased cerebrovascular reactivity on changes of arterial $\mathrm{CO}_{2}$ is associated with a higher risk to develop cerebral ischemia [83]. Until now, this basic physiological regulation mechanism has not been 
Citation: Westermaier T (2013) Neuroprotective Treatment Strategies for Delayed Cerebral Ischemia after Subarachnoid Hemorrhage - Review of Literature and Future Prospects. J Neurol Neurophysiol 5: 183. doi:10.4172/2155-9562.1000183

used therapeutically, although hypercapnia by inhalation of $\mathrm{CO}_{2}$ or by reduction of the respiratory volume in mechanically ventilated patients may rapidly cause an enhancement of CBF. There may be a therapeutic potential to treat patients in a state of critical brain perfusion. A clinical trial investigating this phenomenon is currently on the way (www. clinicaltrials.gov, ID: NCT01799525).

A variety of interesting clinical trials has investigated alternative methods to treat delayed cerebral vasospasm after aneurysmal SAH. The numbers are too small and the investigations not structured enough to implement them into standard therapy yet. However, there may be a high therapeutic potential in these methods and possibly their combinations to treat patients in this critical condition.

\section{Acknowledgements}

This publication was funded by the German Research Foundation (DFG) and the University of Wuerzburg in the funding program "Open Access Publishing"."

\section{References}

1. Rosengart AJ, Schultheiss KE, Tolentino J, Macdonald RL (2007) Prognostic factors for outcome in patients with aneurysmal subarachnoid hemorrhage. Stroke 38: 2315-2321.

2. van Gijn J, Rinkel GJ (2001) Subarachnoid haemorrhage: diagnosis, causes and management. Brain 124: 249-278.

3. Al-Khindi T, Macdonald RL, Schweizer TA (2010) Cognitive and functional outcome after aneurysmal subarachnoid hemorrhage. Stroke 41: e519-536.

4. Jones TH, Morawetz RB, Crowell RM, Marcoux FW, FitzGibbon SJ, et al. (1981) Thresholds of focal cerebral ischemia in awake monkeys. J Neurosurg 54: 773-782.

5. Westermaier T, Jauss A, Eriskat J, Kunze E, Roosen K (2009) Acute vasoconstriction: decrease and recovery of cerebral blood flow after various intensities of experimental subarachnoid hemorrhage in rats. J Neurosurg 110: 996-1002.

6. Hughes JT, Schianchi PM (1978) Cerebral artery spasm. A histological study at necropsy of the blood vessels in cases of subarachnoid hemorrhage. J Neurosurg 48: 515-525.

7. Chaichana KL, Pradilla G, Huang J, Tamargo RJ (2010) Role of inflammation (leukocyte-endothelial cell interactions) in vasospasm after subarachnoid hemorrhage. World Neurosurg 73: 22-41.

8. Fisher CM, Kistler JP, Davis JM (1980) Relation of cerebral vasospasm to subarachnoid hemorrhage visualized by computerized tomographic scanning. Neurosurgery 6: 1-9.

9. Echlin F (1971) Experimental vasospasm, acute and chronic, due to blood in the subarachnoid space. J Neurosurg 35: 646-656.

10. Tertyshnikova S, Yan X, Fein A (1998) cGMP inhibits IP3-induced Ca2+ release in intact rat megakaryocytes via cGMP- and CAMP-dependent protein kinases. J Physiol 512 : 89-96.

11. Marín J, Rodríguez-Martínez MA (1997) Role of vascular nitric oxide in physiological and pathological conditions. Pharmacol Ther 75: 111-134.

12. Takenaka K, Kassell NF, Foley PL, Lee KS (1993) Oxyhemoglobin-induced cytotoxicity and arachidonic acid release in cultured bovine endothelial cells. Stroke 24: 839-845.

13. Toda N, Ayajiki K, Tanaka T, Okamura T (2000) Preganglionic and postganglionic neurons responsible for cerebral vasodilation mediated by nitric oxide in anesthetized dogs. J Cereb Blood Flow Metab 20: 700-708.

14. Giulivi C, Hochstein P, Davies KJ (1994) Hydrogen peroxide production by red blood cells. Free Radic Biol Med 16: 123-129.

15. Gaetani P, Rodriguez y Baena R, Silvani V, Rainoldi F, Paoletti P (1986) Prostacyclin and vasospasm in subarachnoid hemorrhage from ruptured intracranial aneurysm. A preliminary clinical study. Acta Neurol Scand 73: 3338.

16. Seifert V, Löffler BM, Zimmermann M, Roux S, Stolke D (1995) Endothelin concentrations in patients with aneurysmal subarachnoid hemorrhage. Correlation with cerebral vasospasm, delayed ischemic neurological deficits, and volume of hematoma. J Neurosurg 82: 55-62.
17. Gallia GL, Tamargo RJ (2006) Leukocyte-endothelial cell interactions in chronic vasospasm after subarachnoid hemorrhage. Neurol Res 28: 750-758.

18. Brown RJ, Kumar A, Dhar R, Sampson TR, Diringer MN (2013) The relationship between delayed infarcts and angiographic vasospasm after aneurysma subarachnoid hemorrhage. Neurosurgery 72: 702-707.

19. Frontera JA, Fernandez A, Schmidt JM, Claassen J, Wartenberg KE, et al. (2009) Defining vasospasm after subarachnoid hemorrhage: what is the most clinically relevant definition? Stroke 40: 1963-1968.

20. Dreier JP, Ebert N, Priller J, Megow D, Lindauer U, et al. (2000) Products of hemolysis in the subarachnoid space inducing spreading ischemia in the cortex and focal necrosis in rats: a model for delayed ischemic neurological deficits after subarachnoid hemorrhage? J Neurosurg 93: 658-666.

21. Pluta RM (2005) Delayed cerebral vasospasm and nitric oxide: review, new hypothesis, and proposed treatment. Pharmacol Ther 105: 23-56.

22. Muir KW, Lees KR, Ford I, Davis S; Intravenous Magnesium Efficacy in Stroke (IMAGES) Study Investigators (2004) Magnesium for acute stroke (Intravenous Magnesium Efficacy in Stroke trial): randomised controlled trial. Lancet 363 439-445.

23. Hasan D, Lindsay KW, Wijdicks EF, Murray GD, Brouwers PJ, et al. (1989) Effect of fludrocortisone acetate in patients with subarachnoid hemorrhage. Stroke 20: 1156-1161.

24. Mori T, Katayama $Y$, Kawamata T, Hirayama T (1999) Improved efficiency of hypervolemic therapy with inhibition of natriuresis by fludrocortisone in patients with aneurysmal subarachnoid hemorrhage. J Neurosurg 91: 947-952.

25. Hashi K, Takakura K, Sano K, Ohta T, Saito I, et al. (1988) [Intravenous hydrocortisone in large doses in the treatment of delayed ischemic neurological deficits following subarachnoid hemorrhage--results of a multi-center controlled double-blind clinical study]. No To Shinkei 40: 373-382.

26. Feigin VL, Anderson N, Rinkel GJ, Algra A, van Gijn J, et al. (2005) Corticosteroids for aneurysmal subarachnoid haemorrhage and primary intracerebral haemorrhage. Cochrane Database Syst Rev : CD004583.

27. Gomis P, Graftieaux JP, Sercombe R, Hettler D, Scherpereel B, et al (2010) Randomized, double-blind, placebo-controlled, pilot trial of high-dose methylprednisolone in aneurysmal subarachnoid hemorrhage. J Neurosurg 112: 681-688.

28. Braughler JM, Pregenzer JF (1989) The 21-aminosteroid inhibitors of lipid peroxidation: reactions with lipid peroxyl and phenoxy radicals. Free Radic Biol Med 7: 125-130.

29. Zhang S, Wang L, Liu M, Wu B (2010) Tirilazad for aneurysmal subarachnoid haemorrhage. Cochrane Database Syst Rev : CD006778.

30. Lynch JR, Wang H, McGirt MJ, Floyd J, Friedman AH, et al. (2005) Simvastatin reduces vasospasm after aneurysmal subarachnoid hemorrhage: results of a pilot randomized clinical trial. Stroke 36: 2024-2026.

31. Tseng MY, Czosnyka M, Richards H, Pickard JD, Kirkpatrick PJ (2005) Effects of acute treatment with pravastatin on cerebral vasospasm, autoregulation, and delayed ischemic deficits after aneurysmal subarachnoid hemorrhage: a phase II randomized placebo-controlled trial. Stroke 36: 1627-1632.

32. Vergouwen MD, Meijers JC, Geskus RB, Coert BA, Horn J et al. (2009) Biologic effects of simvastatin in patients with aneurysmal subarachnoid hemorrhage: a double-blind, placebo-controlled randomized trial. J Cereb Blood Flow Metab 29: $1444-1453$.

33. Chou SH, Smith EE, Badjatia N, Nogueira RG, Sims JR 2nd, et al. (2008) A randomized, double-blind, placebo-controlled pilot study of simvastatin in aneurysmal subarachnoid hemorrhage. Stroke 39: 2891-2893.

34. Liu Z, Liu L, Zhang Z, Chen Z, Zhao B (2013) Cholesterol-reducing agents for aneurysmal subarachnoid haemorrhage. Cochrane Database Syst Rev 4 CD008184.

35. Wong GK, Liang M, Tan H, Lee MW, Po YC, et al. (2013) High-dose simvastatin for aneurysmal subarachnoid hemorrhage: a multicenter, randomized controlled, double-blind clinical trial protocol. Neurosurgery 72: 840-844.

36. Garg K, Sinha S, Kale SS, Chandra PS, Suri A, et al. (2013) Role of simvastatin in prevention of vasospasm and improving functional outcome after aneurysmal sub-arachnoid hemorrhage: a prospective, randomized, double-blind, placebocontrolled pilot trial. Br J Neurosurg 27: 181-186.

37. Macdonald RL, Kassell NF, Mayer S, Ruefenacht D, Schmiedek P, et al. (2008) 
Citation: Westermaier T (2013) Neuroprotective Treatment Strategies for Delayed Cerebral Ischemia after Subarachnoid Hemorrhage - Review of Literature and Future Prospects. J Neurol Neurophysiol 5: 183. doi:10.4172/2155-9562.1000183

Clazosentan to overcome neurological ischemia and infarction occurring after subarachnoid hemorrhage (CONSCIOUS-1): randomized, double-blind, placebo-controlled phase 2 dose-finding trial. Stroke 39: 3015-3021.

38. Vajkoczy P, Meyer B, Weidauer S, Raabe A, Thome C, et al. (2005) Clazosentan (AXV-034343), a selective endothelin A receptor antagonist, in the prevention of cerebral vasospasm following severe aneurysmal subarachnoid hemorrhage: results of a randomized, double-blind, placebo-controlled, multicenter phase lla study. J Neurosurg 103: 9-17.

39. Shaw MD, Vermeulen M, Murray GD, Pickard JD, Bell BA et al. (2000) Efficacy and safety of the endothelin, receptor antagonist TAK-044 in treating subarachnoid hemorrhage: a report by the Steering Committee on behalf of the UK/Netherlands/Eire TAK-044 Subarachnoid Haemorrhage Study Group. J Neurosurg 93: 992-997.

40. Kramer A, Fletcher J (2009) Do endothelin-receptor antagonists preven delayed neurological deficits and poor outcomes after aneurysmal subarachnoid hemorrhage? a meta-analysis. Stroke 40: 3403-3406.

41. Pickard JD, Murray GD, Illingworth R, Shaw MD, Teasdale GM, et al. (1989) Effect of oral nimodipine on cerebral infarction and outcome after subarachnoid haemorrhage: British aneurysm nimodipine trial. BMJ 298: 636-642.

42. Dorhout MS, Rinkel GJ, Feigin VL, Algra A, van den Bergh WM et al. (2007) Calcium antagonists for aneurysmal subarachnoid haemorrhage. Cochrane Database Syst Rev (3): CD000277.

43. Beck J, Raabe A, Lanfermann H, Berkefeld J, De Rochemont Rdu M, et al (2006) Effects of balloon angioplasty on perfusion- and diffusion-weighted magnetic resonance imaging results and outcome in patients with cerebral vasospasm. J Neurosurg 105: 220-227.

44. Westermaier T, Stetter C, Ernestus RI (2013) Combination therapy for subarachnoid hemorrhage--is nimodipine the wrong partner? J Crit Care 28 1101.

45. Iseri LT, French JH (1984) Magnesium: nature's physiologic calcium blocker Am Heart J 108: 188-193.

46. Altura BM, Altura BT, Carella A, Gebrewold A, Murakawa T, et al. (1987) $\mathrm{Mg}^{2+}-\mathrm{Ca}^{2+}$ interaction in contractility of vascular smooth muscle: $\mathrm{Mg}^{2+}$ versus organic calcium channel blockers on myogenic tone and agonist-induced responsiveness of blood vessels. Can J Physiol Pharmacol 65: 729-745.

47. Dong JF, Cruz MA, Aboulfatova K, Martin C, Choi H et al. (2008) Magnesium maintains endothelial integrity, up-regulates proteolysis of ultra-large von Willebrand factor, and reduces platelet aggregation under flow conditions. Thromb Haemost 99: 586-593.

48. Kh R, Khullar M, Kashyap M, Pandhi P, Uppal R (2000) Effect of oral magnesium supplementation on blood pressure, platelet aggregation and calcium handling in deoxycorticosterone acetate induced hypertension in rats. J Hypertens 18 919-926.

49. Schauf B, Becker S, Abele H, Klever T, Wallwiener D, et al. (2005) Effect of magnesium on red blood cell deformability in pregnancy. Hypertens Pregnancy 24: $17-27$.

50. Peruche B, Krieglstein J (1993) Mechanisms of drug actions against neuronal damage caused by ischemia--an overview. Prog Neuropsychopharmacol Biol Psychiatry 17: 21-70.

51. Nowak L, Bregestovski P, Ascher P, Herbet A, Prochiantz A (1984) Magnesium gates glutamate-activated channels in mouse central neurones. Nature 307 : 462-465.

52. Kristal BS, Dubinsky JM (1997) Mitochondrial permeability transition in the central nervous system: induction by calcium cycling-dependent and -independent pathways. J Neurochem 69: 524-538.

53. Schanne FA, Gupta RK, Stanton PK (1993) 31P-NMR study of transient ischemia in rat hippocampal slices in vitro. Biochim Biophys Acta 1158: 257263.

54. Westermaier T, Zausinger S, Baethmann A, Schmid-Elsaesser R (2005) Dose finding study of intravenous magnesium sulphate in transient focal cerebral ischemia in rats. Acta Neurochir (Wien) 147: 525-532.

55. van den Bergh WM, Algra A, van der Sprenkel JW, Tulleken CA, Rinkel GJ (2003) Hypomagnesemia after aneurysmal subarachnoid hemorrhage. Neurosurgery 52: 276-281.

56. Luo W, Qiu S, Ma W (1996) Clinical study of magnesium sulphate on delayed cerebral vasospasmafter subarachnoid haemorrhage. Journal of Clinical Neurology 9: 244-245.

57. Chia RY, Hughes RS, Morgan MK (2002) Magnesium: a useful adjunct in the prevention of cerebral vasospasm following aneurysmal subarachnoid haemorrhage. J Clin Neurosci 9: 279-281.

58. Veyna RS, Seyfried D, Burke DG, Zimmerman C, Mlynarek M, et al. (2002) Magnesium sulfate therapy after aneurysmal subarachnoid hemorrhage. J Neurosurg 96: 510-514.

59. Prevedello DM, Cordeiro JG, de Morais AL, Saucedo NS Jr, Chen IB, et al. (2006) Magnesium sulfate: role as possible attenuating factor in vasospasm morbidity. Surg Neurol 65: 20

60. Muroi C, Terzic A, Fortunati M, Yonekawa Y, Keller E (2008) Magnesium sulfate in the management of patients with aneurysmal subarachnoid hemorrhage: randomized, placebo-controlled, dose-adapted trial. Surg Neurol 69: 33-39.

61. Stippler M, Crago E, Levy El, Kerr ME, Yonas H, et al. (2006) Magnesium infusion for vasospasm prophylaxis after subarachnoid hemorrhage. J Neurosurg 105: 723-729.

62. van den Bergh WM, Algra A, van Kooten F, Dirven CM, van Gijn J, et al. (2005) Magnesium sulfate in aneurysmal subarachnoid hemorrhage: a randomized controlled trial. Stroke 36: 1011-1015

63. Wong GK, Poon WS, Chan MT, Boet R, Gin T, et al. (2010) Intravenous magnesium sulphate for aneurysmal subarachnoid hemorrhage (IMASH): a randomized, double-blinded, placebo-controlled, multicenter phase III trial. Stroke 41: 921-926.

64. Dorhout Mees SM, Algra A, Vandertop WP, van Kooten F, Kuijsten HA, et al (2012) Magnesium for aneurysmal subarachnoid haemorrhage (MASH-2): a randomised placebo-controlled trial. Lancet 380: 44-49.

65. Golan E, Vasquez DN, Ferguson ND, Adhikari NK, Scales DC (2013) Prophylactic magnesium for improving neurologic outcome after aneurysmal subarachnoid hemorrhage: systematic review and meta-analysis. J Crit Care 28: 173-181.

66. Schmid-Elsaesser R, Kunz M, Zausinger S, Prueckner S, Briegel J, et al (2006) Intravenous magnesium versus nimodipine in the treatment of patients with aneurysmal subarachnoid hemorrhage: a randomized study. Neurosurgery 58: 1054-1065.

67. Westermaier T, Stetter C, Vince GH, Pham M, Tejon JP, et al. (2010) Prophylactic intravenous magnesium sulfate for treatment of aneurysmal subarachnoid hemorrhage: a randomized, placebo-controlled, clinical study. Crit Care Med 38: 1284-1290

68. Gules I, Satoh M, Clower BR, Nanda A, Zhang JH (2002) Comparison of three rat models of cerebral vasospasm. Am J Physiol Heart Circ Physiol 283: H2551-2559.

69. Nosko M, Weir BK, Lunt A, Grace M, Allen P, et al. (1987) Effect of clot removal at 24 hours on chronic vasospasm after SAH in the primate model. J Neurosurg 66: 416-422.

70. Tsuji T, Cook DA, Weir BK, Handa Y (1996) Effect of clot removal on cerebrovascular contraction after subarachnoid hemorrhage in the monkey: pharmacological study. Heart Vessels 11: 69-79.

71. Tsementzis SA, Honan WP, Nightingale S, Hitchcock ER, Meyer CH (1990) Fibrinolytic activity after subarachnoid haemorrhage and the effect of tranexamic acid. Acta Neurochir (Wien) 103: 116-121.

72. Hamada J, Mizuno T, Kai Y, Morioka M, Ushio Y (2000) Microcatheter intrathecal urokinase infusion into cisterna magna for prevention of cerebral vasospasm: preliminary report. Stroke 31: 2141-2148.

73. Yamamoto T, Esaki T, Nakao Y, Mori K (2010) Efficacy of low-dose tissueplasminogen activator intracisternal administration for the prevention of cerebral vasospasm after subarachnoid hemorrhage. World Neurosurg 73: 675-682.

74. Kawamoto S, Tsutsumi K, Yoshikawa G, Shinozaki MH, Yako K, et al. (2004) Effectiveness of the head-shaking method combined with cisternal irrigation with urokinase in preventing cerebral vasospasm after subarachnoid hemorrhage. J Neurosurg 100: 236-243.

75. Suzuki IS, Takahashi H (2013) Effect of head-shaking method on clot removal in cisternal irrigation. Sano K: Cerebral Vasospasm Tokyo, University of Tokyo Press, 314-316.

76. Eicker SO, Beseoglu K, Etminan N, Perrin J, Taskin A, et al. (2012) The effect of intraventricular thrombolysis in combination with low-frequency head 
Citation: Westermaier T (2013) Neuroprotective Treatment Strategies for Delayed Cerebral Ischemia after Subarachnoid Hemorrhage - Review of Literature and Future Prospects. J Neurol Neurophysiol 5: 183. doi:10.4172/2155-9562.1000183

motion after severe subarachnoid hemorrhage: interim analysis of safety, clot clearance rate and delayed cerebral ischemia. Acta Neurochir Suppl 114: 323328.

77. Pyne GJ, Cadoux-Hudson TA, Clark JF (2001) Magnesium protection against in vitro cerebral vasospasm after subarachnoid haemorrhage. $\mathrm{Br} \mathrm{J}$ Neurosurg 15: 409-415.

78. Kimura T, Yasue H, Sakaino N, Rokutanda M, Jougasaki M, et al. (1989) Effects of magnesium on the tone of isolated human coronary arteries. Comparison with diltiazem and nitroglycerin. Circulation 79: 1118-1124.

79. Mori K, Yamamoto T, Nakao Y, Osada H, Hara Y, et al. (2009) Initial clinical experience of vasodilatory effect of intra-cisternal infusion of magnesium sulfate for the treatment of cerebral vasospasm after aneurysmal subarachnoid hemorrhage. Neurol Med Chir (Tokyo) 49: 139-144

80. Diringer MN, Kirsch JR, Hanley DF, Traystman RJ (1993) Altered cerebrovascular $\mathrm{CO} 2$ reactivity following subarachnoid hemorrhage in cats. $J$ Neurosurg 78: 915-921.

81. Schmieder K, Jarus-Dziedzic K, Wronski J, Harders A (1997) CO2 reactivity in patients after subarachnoid haemorrhage. Acta Neurochir (Wien) 139: 10381041.

82. Hassler W, Chioffi $F$ (1989) CO2 reactivity of cerebral vasospasm after aneurysmal subarachnoid haemorrhage. Acta Neurochir (Wien) 98: 167-175.

83. Carrera E, Kurtz P, Badjatia N, Fernandez L, Claassen J, et al. (2010) Cerebrovascular carbon dioxide reactivity and delayed cerebral ischemia after subarachnoid hemorrhage. Arch Neurol 67: 434-439.

84. Shibuya M, Suzuki Y, Enomoto H, Okada T, Ogura K, et al. (1994) Effects of prophylactic intrathecal administrations of nicardipine on vasospasm in patients with severe aneurysmal subarachnoid haemorrhage. Acta Neurochir (Wien) 131: 19-25.

85. Suzuki M, Doi M, Otawara Y, Ogasawara K, Ogawa A (2001) Intrathecal administration of nicardipine hydrochloride to prevent vasospasm in patients with subarachnoid hemorrhage. Neurosurg Rev 24: 180-184.

86. Fujiwara K, Mikawa S, Ebina T (2001) [Continuous intrathecal administration of nicardipine using a portable infusion pump system for management of vasospasm after subarachnoid hemorrhage]. No Shinkei Geka 29: 23-30.

87. Ehtisham A, Taylor S, Bayless L, Samuels OB, Klein MW, et al. (2009) Use of intrathecal nicardipine for aneurysmal subarachnoid hemorrhage-induced cerebral vasospasm. South Med J 102: 150-153.
88. Goodson K, Lapointe M, Monroe T, Chalela JA (2008) Intraventricula nicardipine for refractory cerebral vasospasm after subarachnoid hemorrhage. Neurocrit Care 8: 247-252.

89. Hänggi D, Beseoglu K, Turowski B, Steiger HJ (2008) Feasibility and safety of intrathecal nimodipine on posthaemorrhagic cerebral vasospasm refractory to medical and endovascular therapy. Clin Neurol Neurosurg 110: 784-790.

90. Thomas JE, Rosenwasser RH, Armonda RA, Harrop J, Mitchell W, et al. (1999) Safety of intrathecal sodium nitroprusside for the treatment and prevention of refractory cerebral vasospasm and ischemia in humans. Stroke 30: 1409-1416.

91. Thomas JE, McGinnis G (2002) Safety of intraventricular sodium nitroprusside and thiosulfate for the treatment of cerebral vasospasm in the intensive care unit setting. Stroke 33: 486-492.

92. Raabe A, Zimmermann M, Setzer M, Vatter H, Berkefeld J, et al. (2002) Effect of intraventricular sodium nitroprusside on cerebral hemodynamics and oxygenation in poor-grade aneurysm patients with severe, medically refractory vasospasm. Neurosurgery 50: 1006-1013

93. Pathak A, Mathuriya SN, Khandelwal N, Verma K (2003) Intermittent low dose intrathecal sodium nitroprusside therapy for treatment of symptomatic aneurysmal SAH-induced vasospasm. Br J Neurosurg 17: 306-310.

94. Kumar R, Pathak A, Mathuriya SN, Khandelwal N (2003) Intraventricula sodium nitroprusside therapy: a future promise for refractory subarachnoid hemorrhage-induced vasospasm. Neurol India 51: 197-202.

95. Dalbasti T, Karabiyikoglu M, Ozdamar N, Oktar N, Cagli S (2001) Efficacy of controlled-release papaverine pellets in preventing symptomatic cerebra vasospasm. J Neurosurg 95: 44-50.

96. Kasuya H, Onda H, Sasahara A, Takeshita M, Hori T (2005) Application of nicardipine prolonged-release implants: analysis of 97 consecutive patients with acute subarachnoid hemorrhage. Neurosurgery 56: 895-902.

97. Krischek B, Kasuya H, Onda H, Hori T (2007) Nicardipine prolonged-release implants for preventing cerebral vasospasm after subarachnoid hemorrhage: effect and outcome in the first 100 patients. Neurol Med Chir (Tokyo) 47: 389394.

98. Barth M, Capelle HH, Weidauer S, Weiss C, Münch E, et al. (2007) Effect of nicardipine prolonged-release implants on cerebral vasospasm and clinical outcome after severe aneurysmal subarachnoid hemorrhage: a prospective, randomized, double-blind phase lla study. Stroke 38: 330-336.
This article was originally published in a special issue, Neurosurgery handled by Editor(s). Dr. loannis Karakis, Harvard Medical School, United States 